\title{
ANALISIS POTENSI REFUSE DERIVED FUEL (RDF) DARI SAMPAH PADA TEMPAT PEMBUANGAN AKHIR (TPA) DI KABUPATEN TEGAL SEBAGAI BAHAN BAKAR INCINERATOR PIROLISIS
}

\author{
Mutiara Fadila Rania ${ }^{1, *}$, I Gede Eka Lesmana ${ }^{2}$, Eka Maulana ${ }^{3}$ \\ Jurusan Teknik Mesin Universitas Pancasila \\ J1.Srengseng Sawah, Jagakarsa, RT.1/RW.3, Jagakarsa Jakarta Selatan, 12640, Indonesia \\ *E-mail: mutiara98.29@gmail.com
}

Diterima: 13-03-2019

Direvisi: 27-05-2019

Disetujui: 01-06-2019

\begin{abstract}
ABSTRAK
Tempat pembuangan sampah di Kabupaten Tegal telah mencapai 989,8 m3 / hari dan meningkat setiap tahun. Persentase sampah di TPA Murareja didominasi oleh sampah plastik yaitu 40,15\%. Sampah plastik akan diolah secara pirolisis dengan menggunakan bahan bakar Refuse Derived (RDF) sebagai bahan bakarnya. Persentase sampah di TPA Murareja yang dapat digunakan sebagai RDF cukup tinggi, yaitu 28,7\%, terdiri dari 15,35\% limbah kertas, limbah karet / kulit 2,35\%, kain sampah 2\%, kain sampah $2 \%$, limbah kayu $1 \%$, dan plastik $8 \%$ limbah. Limbah tersebut dianggap berpotensi untuk diproduksi menjadi RDF. Produksi RDF bertujuan untuk mengubah fraksi limbah yang mudah terbakar dari limbah 4K1P (Kertas, Kayu, Kain, Karet / Kulit dan Plastik) menjadi bahan bakar. Oleh karena itu penting untuk mengetahui seberapa besar potensi limbah 4K1P untuk diolah menjadi RDF, dan seberapa optimal nilai kalor RDF akan digunakan sebagai bahan bakar pirolisis insinerator pada Pembangkit Tenaga Sampah di Pembangkit Tenaga Sampah di TPA Murareja, Kabupaten Tegal. Berdasarkan hasil penelitian yang telah dilakukan, nilai teoritis dari nilai teoritis briket RDF 4K1P adalah $3677,0945-5507,114$ [kkal $/ \mathrm{kg}$ ]. Dari data aktual yang diperoleh dengan pengujian laboratorium, nilai limbah kalor minuman RDF 4K1P RDF berjumlah 3973,45 [kCal / kg]. Nilai kalor optimal RDF yang diperlukan sebagai bahan bakar pembakaran pirolisis adalah 3248,809 [kkal/ kg]. Berdasarkan hasil uji laboratorium, persentase kadar air, kadar abu, kadar volatil dan kadar karbon masing-masing adalah 4,68\%, 11,64\%, 7,81\% dan $75,87 \%$.
\end{abstract}

Kata kunci: limbah, RDF, nilai kalor. Insinerator.

\section{ABSTRACT}

The garbage dumping in Tegal Regency has reached $989.8 \mathrm{~m} 3 /$ day and increasing every year. The percentage of waste in Murareja landfill is dominated by plastic waste which is $40.15 \%$. The plastic waste will be processed by pyrolysis by utilizing Refuse Derived Fuel (RDF) as its fuel. The percentage of garbage in Murareja TPA that can be used as RDF is quite high, which is $28.7 \%$, consisting of $15.35 \%$ paper waste, $2.35 \%$ rubber / leather waste, $2 \%$ garbage cloth, $1 \%$ wood waste, and $8 \%$ plastic waste. The waste is considered potentially to be produced into RDF. The production of RDF aims to convert the combustible waste fraction from $4 K 1 P$ waste (Paper, Wood, Fabrics, Rubber / Leather and Plastics) to be fueled. Therefore it is important to know how much potential of $4 K 1 P$ waste to be processed into RDF, and how optimal calorific value of RDF is to be used as fuel of pyrolysis incinerator on Waste Power Generation at Murareja TPA, Tegal regency. Based on the result of the 
research that has been done, the theoretical value of the theoretical value of $4 K 1 P$ RDF briquette is 3677.0945 5507.114 [kcal / kg]. From the actual data obtained with laboratory testing the value of RDF beverage caloric waste 4KIP RDF amounted to 3973.45 [kCal / kg]. The optimal calorific value of RDF required as a pyrolysis incinerator fuel is 3248.809 [kcal / kg]. Based on the results of laboratory tests, the percentage of moisture content, ash content, volatile content and carbon content are $4.68 \%, 11.64 \%, 7.81 \%$ and $75.87 \%$ respectively.

Keywords: waste, RDF, calorific value. Incinerator.

\section{PENDAHULUAN}

Penumpukan sampah di Indonesia kini masih menjadi masalah yang belum terselesaikan, penimbunan sampah di berbagai TPA dan TPS di kota - kota besar di Indonesia banyak menimbulkan berbagai macam permasalahan, antara lain pencemaran udara, pencemaran air, pembawa bibit penyakit hingga longsor.

Dalam Undang-Undang Republik Indonesia Nomor 18 tahun 2008 tentang Pengelolaan Sampah dinyatakan bahwa saat ini pengelolaan sampah masih belum sesuai dengan metode dan pengelolaan sampah yang berwawasan lingkungan sehingga dapat berpotensi menimbulkan dampak negatif terhadap kesehatan.

Salah satu daerah di Pulau Jawa yang menjadi perhatian pada masalah sampah kali ini adalah Kabupaten Tegal. Penumpukan sampah di Kabupaten Tegal sudah mencapai kondisi yag sangat serius. Volume sampah di Kabupaten Tegal terus meningkat seiring dengan pertumbuhan pendudukan, untuk tahun 2014 volume sampah mencapai $989.8 \mathrm{~m}^{3}$ perhari.

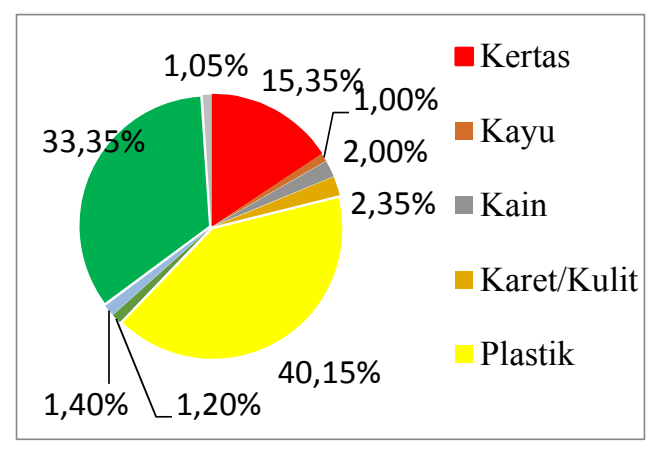

Gambar 1. Komposisi Sampah di Kabupaten Tegal tahun 2014, [1]

Timbunan sampah di Kabupatan Tegal yang mencapai $989.8 \mathrm{~m}^{3}$ setiap harinya dengan komposisi $40.15 \%$ sampah plastik, 33.5\% sampah organik, $2.60 \%$ sampah metal,gelas dan kaca, 20.7\% sampah kertas, kayu, kain dan karet/kulit, dan $1.05 \%$ sampah lainnya menimbulkan masalah jika tidak dikelola dengan baik.

Dengan didominasi oleh banyaknya sampah plastik, maka pada perencanaan pembangunan Pembangkit Listrik Tenaga Sampah (PLTSa) di Kabupaten Tegal, dibuat sistem pengolahan sampah plastik tersebut secara pirolisis. Dalam kajian ini, dibahas mengenai peran RDF sebagai bahan bakar incinerator pirolisis.

Melihat persentase sampah kertas, kayu, kain dan karet/kulit sebesar 28.7\%, diharapkan sampah 4K1P (Kertas, Kayu, Kain, Karet/kulit dan Plastik) tersebut dapat diolah menjadi RDF sebagai energi alternatif pengganti bahan bakar fosil untuk menangani sampah yang belum dikelola tersebut.

\section{METODE PENELITIAN}

\subsection{Karakteristik Limbah Padat}

Limbah padat atau yang sering dikenal dengan sampah adalah hasil buangan industri / rumah tangga yang berupa padatan, lumpur atau bubur yang berasal dari proses pengolahan.

- Karakteristik Limbah Padat

Limbah padat atau yang lebih dikenal dengan sampah mempunyai karakteristik fisik, kimia dan biologis.

- Refuse Derived Fuel (RDF)

Refuse Derived Fuel (RDF) adalah hasil proses pemisahan limbah padat fraksi sampah mudah terbakar dan tidak mudah terbakar seperti metal dan kaca RDF mampu mereduksi jumlah sampah dan menjadi co-combustion, bahan bakar sekunder industri semen dan industri pembangkit listrik. Dalam pembuatan RDF, fraksi sampah yang mudah terbakar pada 
umumnya dilakukan reduksi ukuran lalu dikeringkan supaya dapat digunakan sebagai bahan bakar, [2].

\subsection{Karakteristik dan Standar RDF}

Terdapat beberapa parameter yang digunakan dalam mengolah sampah menjadi $\mathrm{RDF}$, antara lain nilai kalor, kadar air, kadar abu, dan kadar volatil.

a. Nilai Kalor

Nilai kalor merupakan sejumlah energi yang dilepaskan per unit massa atau per unit volume dari suatu material atau bahan ketika material tersebut habis terbakar (ASABE S593.1., 2011).

Nilai kalori terbagi atas dua yaitu Higher Heating Value (HHV) dan Lower Heating Value (LHV). Keduanya memuliki acuan dan metode perhitungan yang sedikit berbeda, selain itu terdapat pula perbedaan kandungan air pada setiap reaksi pembakaran hidrokarbon.

b. Kadar Air (Moisture Content)

Perhitungan persentase kadar air (moisture content) yang terkandung di dalam RDF tersebut menggunakan standar ASTM D3173-03 dengan persamaan sebagai berikut:

$\mathrm{MC}=\frac{(a-b)}{a} \times 100 \%$

Dimana :

$$
\begin{aligned}
\mathrm{MC}= & \text { moisture content } \\
\mathrm{a}= & \text { massa awal RDF [gram }] \\
\mathrm{b}= & \text { masssa RDF setelah pemanasan } \\
& 107^{\circ} \mathrm{C}[\text { gram }]
\end{aligned}
$$

c. Kadar Abu (Ash Content)

Abu yang terkandung dalam bahan bakar padat adalah mineral yang tidak dapat terbakar, tertinggal setelah proses pembakaran dan reaksi-reaksi yang menyertainya selesai. Abu berperan menurunkan mutu bahan bakar padat karena dapat menurunkan nilai kalor.

Perhitungan persentase kadar abu RDF menggunakan standar ASTM D-3174-04 dengan persamaan sebagai berikut:

$$
\mathrm{AC}=\frac{d}{a} \times 100 \%
$$

Dimana :

$$
\begin{aligned}
\mathrm{AC}= & \text { Ash Content }(\%) \\
\mathrm{d}= & \text { massa } \mathrm{RDF} \text { setelah pemanasan } 750 \\
& \left.{ }^{\circ} \mathrm{C} \text { [gram }\right] \\
\mathrm{a} \quad= & \text { massa awal RDF }[\text { gram }]
\end{aligned}
$$

c. Kadar Zat yang Menguap (Volatile Matter) Volatile Matter (VM) atau sering disebut dengan zat terbang, berpengaruh terhadap pembakaran briket RDF. Semakin banyak kandungan volatile matter pada RDF maka RDF akan semakin mudah untuk terbakar dan menyala, [3].

Perhitungan persentase kadar volatile yang terkandung di dalam briket menggunakan standar ASTM D-3175-02 dengan persamaan sebagai berikut:

$\mathrm{VM}=\frac{b-c}{a} \times 100 \%$

Dimana :

$$
\begin{aligned}
\mathrm{VM}= & \text { Volatile mstter }(\%) \\
\mathrm{c}= & \text { massa RDF setelah pemanasan } 950^{\circ} \mathrm{C} \\
& \text { temperature [gram] }
\end{aligned}
$$

\subsection{Model Empiris Prediksi Energi dari Sampah}

Variabel bebas di dalam modelisasi empiris nilai kalor sampah adalah elemen komposisi. Berikut dapat dilihat analisa kandungan nilai kalor sampah dengan cara perhitungan menggunakan beberapa model dengan komponen yang diketahui, yaitu berupa komponen fisik dan analisa proksimat.

\section{- Analisa Komposisi Fisik}

a. Model Konvensional

$$
\mathrm{Hn}=88.2 \mathrm{R}+40.5(\mathrm{G}+\mathrm{P})-6 \mathrm{~W}
$$

Dimana :

$\mathrm{Hn}=$ net calorific value $[\mathrm{kcal} / \mathrm{kg}]$

$\mathrm{R}=$ plastik $(\%$ berat kering $)$

$\mathrm{G}=$ sampah organic $(\%$ berat kering $)$

$\mathrm{P}=$ kertas (\% berat kering)

$\mathrm{W}=$ kadar air $(\%$ berat kering $)$ 
b. Model Khan dan Abu Gharah

$\mathrm{E}=23(\mathrm{~F}+3.6(\mathrm{PA}))+160(\mathrm{PL})$

Dimana :

$\mathrm{E}=$ kandungan energi sampah $[\mathrm{Btu} / \mathrm{lb}]$

$\mathrm{PL}=$ persentase berat plastik

$\mathrm{F}=$ persentase berat sampah makanan

$\mathrm{PA}=$ persentase berat kertas

\section{- Analisis Ultimate}

a. Model Dulong

$\mathrm{Hn}=81 \mathrm{C}+342.5\left(H-\frac{0}{8}\right)+22.5 \mathrm{~S}-$
$6(9 \mathrm{H}+\mathrm{W})$

Dimana :

$\mathrm{Hn}=$ net calorific value $[\mathrm{kcal} / \mathrm{kg}]$

$\mathrm{C}=$ karbon $(\mathrm{wt} \%)$

$\mathrm{H}=$ hydrogen $(\mathrm{wt} \%)$

$\mathrm{O}=$ oksigen $(\mathrm{wt} \%)$

$\mathrm{S}=\operatorname{sulfur}(\mathrm{wt} \%)$

b. Model Stener

$\mathrm{Hn}=81\left(\mathrm{C}-\frac{30}{8}\right)+57\left(\frac{30}{8}\right)+345\left(-\frac{0}{16}\right)$
$+25 \mathrm{~S}-6(9 \mathrm{H}+\mathrm{W})$

c. Model Scheurer-Kestner

$\mathrm{Hn}=81\left(\mathrm{C}-\frac{30}{4}\right)+342.5 \mathrm{H}+25 \mathrm{~S}+57\left(\frac{30}{4}\right)-$

$6(9 \mathrm{H}+\mathrm{W})$

- Analisis Proximate

a. Model Tradisional

$\mathrm{Hn}=45 \mathrm{~B}-6 \mathrm{~W}$

Dimana :

$\mathrm{B}=$ combustible volatile matter

$\mathrm{W}=$ kadar air ( $\%$ dry basis $)$

b. Model Bento

$\mathrm{Hn}=44.75 \mathrm{~B}-5.8 \mathrm{~W}+21.2$

c. Model Tchobanoglous

Kandungan energi $=\frac{\sum A x B}{\sum B}$

Dimana :

$\mathrm{A}=$ kandungan energi tiap komponen sampah $[\mathrm{kcal} / \mathrm{kg}]$
$\mathrm{B}=$ berat sampah $[\mathrm{kg}]$

d. Model Mrus

$\operatorname{HHVc}=\operatorname{HHVwc} /\left(\frac{C}{100}\right)$
$\operatorname{HHV}_{\mathrm{RDF}}=\operatorname{HHVc}\left(1-\frac{N+M}{100}\right)$

Dimana :

$\mathrm{N}=$ persentase material noncombustible seperti material inorganic, inert (\%)

$\mathrm{M}=$ persentase kadar air dalam sampah $(\%)$

$\mathrm{c}=$ persentase fraksi combustible $(\%)$

$\mathrm{HHV}_{\mathrm{RDF}}=$ kandungan energi dalam RDF $[\mathrm{kcal} / \mathrm{kg}]$

$\mathrm{HHVc}=$ kandungan energi sampah combustible dalam 100\% sampah $[\mathrm{kcal} / \mathrm{kg}]$

$\mathrm{HHVwc}=$ kandungan energi sampah combustible $[\mathrm{kcal} / \mathrm{kg}]$

\subsection{Kesetimbangan Energi Pada Ruang Bakar}

Kesetimbangan energi merupakan salah satu parameter penting untuk mengetahui kinerja dari seluruh sistem pembakaran. Prinsip kesetimbangan energi digunakan untuk mengetahui energi dalam bentuk panas yang digunakan secara efektif pada suatu sistem.

\section{- Perhitungan Nilai Kalor Kebutuhan Insenerator Pirolisis}

Insenerator adalah suatu alat pembakar sampah yang dioperasikan dengan menggunakan teknologi pada suhu tertentu, sehingga sampah dapat terbakar habis.

Pehitungan nilai kalor optimal yang dibutuhkan incinerator pirolisis dijabarkan pada persamaan berikut, [4]:

$\mathrm{Np}=\frac{\text { Qtotal }}{\text { Waxt } \times \eta}$

Dimana :

$\mathrm{Np}=$ nilai kalor bahan bakar yang dibutuhkan $[\mathrm{kJ} / \mathrm{kg}]$

Qtotal $=$ kalor total yang dibutuhkan dalam pemanasan pada reaktor $[\mathrm{kJ}]$

$\mathrm{t}=$ waktu untuk mencairkan plastik [jam] 
$\eta \quad=$ efisiensi ruang bakar incinerator [\%]

$\mathrm{Wa}=$ laju pembakaran bahan bakar $[\mathrm{kg} / \mathrm{jam}]$

\section{- Diagram Alir Penelitian}

Prosedur penelitian ini digambarkan sebagai diagram alir pada gambar 2 .

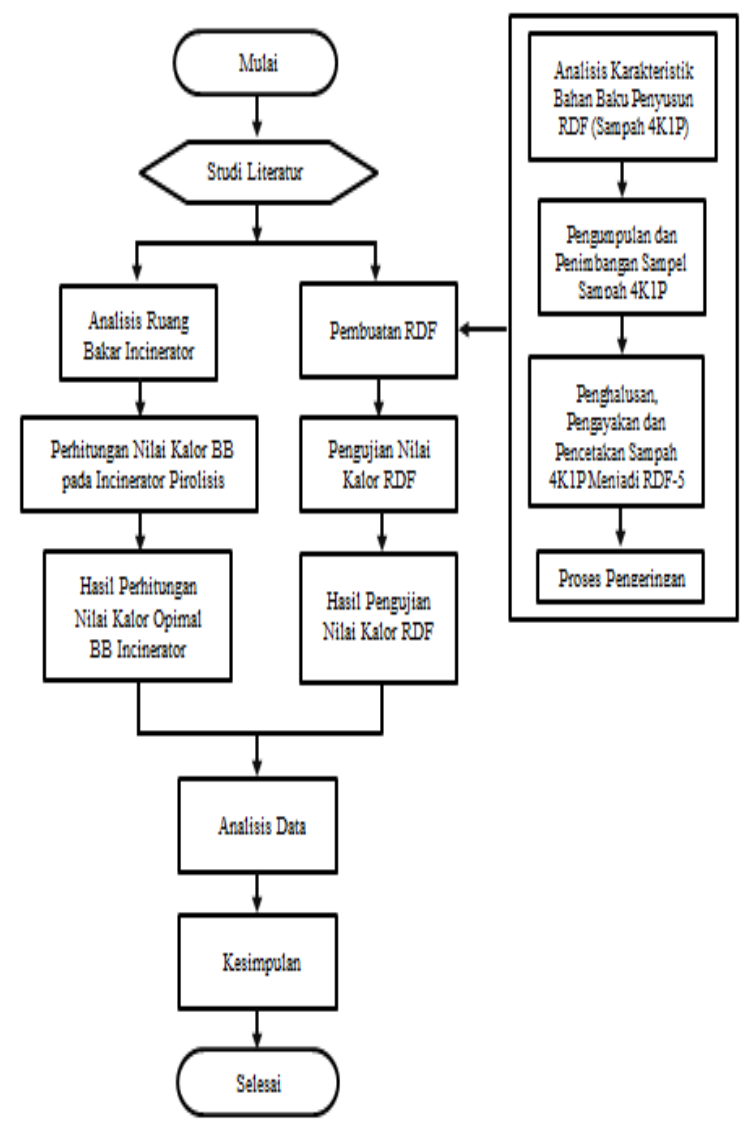

Gambar 2. Diagram Alir Penelitian

\section{- Proses Pembuatan dan Pengujian Briket RDF}

a. Pengumpulan Bahan Baku

Bahan baku berupa sampah 4K1P (kertas, kayu, kain, karet/kulit dan plastik)

dikumpulkan pada wadah terpisah dengan berat masing-masing $1 \mathrm{~kg}$.

b. Reduksi Ukuran Partikel Sampah

Reduksi ukuran pada sampah yang telah dikumpulkan merupakan unit operasi yang paling penting dalam pengolahan limbah padat menjadi RDF, dengan mereduksi ukuran partikel sampah dapat memberikan keseragaman pada masing-masing kompoenen sampah. Reduksi ukuran sampah yang umum di fasilitas pengolahan sampah sampai ukuran sekitar 5-10 cm. Reduksi sampah menjadi ukuran partikel yang lebih kecil dilakukan dengan mencacah nya dengan mesin Shredder sampah.

c. Pengayakan

Agar ukuran tiap jenis sampah sama, maka dilakukan pengayakan sampah yang telah dicacah tersebut dengan saringan ukuran kelolosan 35 mesh atau setara dengan 0.5 $\mathrm{mm}$.

d. Menimbang Bahan Baku

Menimbang bahan baku dengan komposisi yang telah ditentukan sebelumnya dengan menggunakan timbangan digital.

e. Setelah semua bahan baku diayak dan disaring, langkah selanjutnya adalah mencampur seluruh bahan baku dengan persentase yang mengacu pada Gambar I-1 Didapatkan persentase sampah 4K1P senilai $28.7 \%$, yang terdiri dari $15.35 \%$ sampah kertas, 1\% sampah kayu, 2\% sampah kain, dan $2.35 \%$ sampah karet/kulit dengan tambahan 8\% sampah plastik. Setelah semua bahan baku tercampur, terlebih dahulu ditambahkan perekat agar briket RDF tidak mudah rapuh. Perekat yang ditambahkan adalah kanji dengan persentase $10 \%$ dari massa briket.

f. Pencetakan Briket RDF

Setelah semua bahan tercampur rata, langkah selanjutnya adalah mencetak briket dengan menggunakan alat pencetak briket dengan menggunakan beban $25 \mathrm{~kg}$.

g. Pengeringan Briket RDF

Setelah dilakukan proses pencetakan, kemudian briket dijemur dibawah terik matahari selama 7 hari. Proses pengeringan ini bertujuan untuk mengurangi kadar air yang terdapat dalam briket.

h. Pengujian Briket RDF

Terdapat 5 tahap pengujian Briket RDF, yaitu pengujian Nilai kalor, kadar abu, kadar air dan titik nyala. 


\section{- Pengujian Kadar Air}

Pengukuran kadar air merupakan suatu cara untuk mengukur banyaknya air yang terdapat di dalam suatu bahan. Kadar air pada sampel briket ini ditentukan dengan metode penjemuran di bawah sinar matahari. Setelah proses pencetakan, sampel ditimbang dengan timbangan digital kemudian dijemur di bawah terik matahari selama 5 hari. Setelah itu sampel disimpan di dalam wadah yang diletakkan di ruangan yang tidak terkena cahaya matahari. Kemudian sampel diukur kembali bobotnya secara teliti.

\section{- Uji Kadar Abu}

Kadar abu merupakan residu anorganik yang terdapat dalam suatu bahan. Pengukuran kadar abu dalam proses pembakaran pada briket dilakukan dengan membakar briket sampai habis terbakar. Setelah itu abu sisa pembakaran diambil kemudian ditimbang.

\section{- Pengujian Nilai Kalor}

Pengujian nilai kalor briket RDF dilakukan dengan menggunakan pengujian laboratorium yang menggunakan Bomb Calorimeter dan Perhitungan teoritis nilai kalor sampah dari data statistic yang telah diperoleh dari penelitian sebelumnya.

\section{- Pegujian Laboratorium}

Pengujian ini dilakukan dengan menggunakan 5 sampel briket RDF dengan mengambil \pm 1 gr dari berat masing-masing sampel.

\section{- Perhitungan Nilai Kalor Sampah}

Perhitungan nilai kalor sampah secara keseluruhan dilakukan dengan perhitungan komposisi fisik sampah, dikalikan dengan data nilai kalor yang tersedia dari percobaan sebelumnya. Pada perhitungan nilai kalor ini digunakan rumus perhitungan Higher Heating Value (HHV).

\section{HASIL DAN PEMBAHASAN}

\subsection{Perhitungan Nilai Kalor Teoritis}

Perhitungan nilai kalor teoritis pada penelitian ini digunakan 5 literatur yang melakukan penelitian mengenai nilai kalor terdahulu. Pada perhitungan nilai kalor teoritis ini diambil dari data statistik dengan perhitungan kandungan energi yang menggunakan analisa proksimat model Tchobanoglous yang tertera pada persamaan 11.

Tabel 1. Hasil Perhitungan Nilai Kalor Teoritis

\begin{tabular}{|l|c|}
\hline \multicolumn{1}{|c|}{ Referensi } & Nilai Kalor (kcal/kg) \\
\hline Trang\&Lee & 5253.380 \\
\hline Mrus\&Prendergast & 5506.362 \\
\hline Maria\&Pavesi & 4524.084 \\
\hline Sayid B & 4933.863 \\
\hline Antonopoulus & 5020.543 \\
\hline Anugrah SJ & 3677.095 \\
\hline Rata-rata & 4819.220 \\
\hline Sumber: Olahan Pemulis, 2017
\end{tabular}

Dari perhitungan yang dihasilkan berdasarkan ke-enam referensi, nilai kalor tertingg sebesar $5506.362[\mathrm{kcal} / \mathrm{kg}]$ yang diperoleh dari referensi Mrus \& Prendergast. Dan nilai kalor terendah adalah $3677.0945 \quad[\mathrm{kcal} / \mathrm{kg}]$ yang diperoleh dari referensi Anugrah Sari Juwita 2012. Perbedaan nilai kalor dari kelima referensi tersebut disebabkan karena penggunaan data sekunder dari literatur untuk komposisi kimiawi sampah. Hal ini dapat disebabkan karena komposisi kimiawi tiap sampel yang diujikan berbeda pada masingmasing negara. Berdasarkan data pada Tabel IV-7 diatas, rata-rata yang diperoleh dari ke lima referensi nilai kalor adalah sebesar 4819.220 [kcal $/ \mathrm{kg}]$, nilai kalor tersebut telah memenuhi standar nilai kalor briket biobatubara sesuai dengan Permen ESDM No.047 Tahun $2006^{[3]}$,dengan standar nilai kalor sebesar $4400[\mathrm{kcal} / \mathrm{kg}]$.

\subsection{Perhitungan Nilai Kalor Kebutuhan Insenerator Pirolisis}

Spesifikasi insenerator pada reaktor pirolisis yang digunakan pada perhitungan ini adalah sebagai berikut: 
- Kapasitas plastik $=5[\mathrm{~kg}]$

- Laju pembakaran $=2 \mathrm{~kg} / \mathrm{jam}$

- Temperatur pemanasan reaktor pirolisis $=$ $478\left[{ }^{\circ} \mathrm{C}\right]$

- $\quad$ Material = stainless steel

- Temperatur ruang bakar $=800\left[{ }^{\circ} \mathrm{C}\right]$

- Waktu pemanasan $=1$ jam

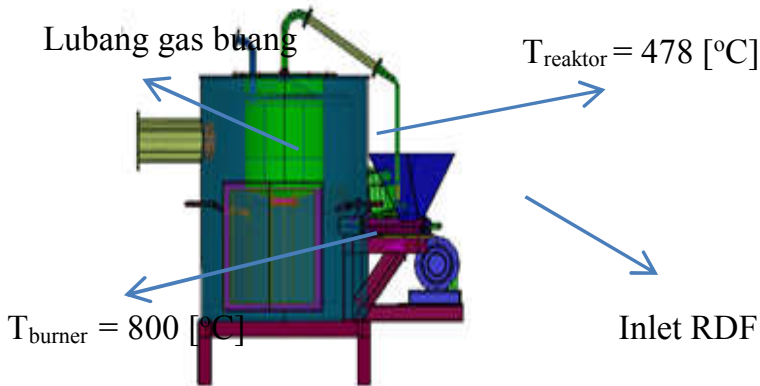

Gambar 3. Insenerator Pirolisis

Pehitungan nilai kalor optimal yang dibutuhkan incinerator pirolisis menggunakan rumus yang dijabarkan pada persamaan (13). Untuk mengetahui berapa nilai kalor optimal yang dibutuhkan insenerator, maka dilakukan perhitungan kalor berdasarkan analisa grafik kalor lebur plastik LDPE yang diketahui karakteristiknya.

Pemanasan awal pada plastik sebelum memasuki reaktor pirolisis diasumsikan memiliki suhu sebesar $\mathrm{T}_{0}=100^{\circ} \mathrm{C}$, yang dihasilkan dari panas buang hasil pirolisis. Maka dapat dilakukan analisa perhitungan sebagai berikut:

\section{- Mencari Qtotal}

$$
\begin{aligned}
& \text { Qtotal }=\mathrm{Q} 1+\mathrm{Q} 2+\mathrm{Q} 3+\mathrm{Q} 4+\mathrm{Q} 5 \\
& \mathrm{Q} 1=\mathrm{m} \cdot \mathrm{C}_{\mathrm{pLDPE}} \cdot\left(\mathrm{T}_{1}-\mathrm{T}_{0}\right) \\
& =5 \mathrm{~kg} \times 2300 \mathrm{~J} / \mathrm{kg}{ }^{\circ} \mathrm{C} \times(112- \\
& \text { 100) }{ }^{\circ} \mathrm{C} \\
& =138000 \mathrm{~J} \\
& =138 \mathrm{~kJ} \\
& \text { Q2 } \quad=\mathrm{m} . \mathrm{L}_{\mathrm{LDPE}} \\
& =5 \mathrm{~kg} \times 98000 \mathrm{~J} / \mathrm{kg}^{\circ} \mathrm{C} \\
& =490000 \mathrm{~J} \\
& =490 \mathrm{~kJ} \\
& \text { Q3 }=\mathrm{m} \cdot \mathrm{C}_{\mathrm{pLDPE}} \cdot\left(\mathrm{T}_{2}-\mathrm{T}_{1}\right) \\
& =5 \mathrm{~kg} \times 2300 \mathrm{~J} / \mathrm{kg}{ }^{\circ} \mathrm{C} \times(300- \\
& \text { 112) }{ }^{\circ} \mathrm{C} \\
& =2162000 \mathrm{~J} \\
& =2162 \mathrm{~kJ} \\
& \mathrm{Q} 4=\mathrm{m} \times \mathrm{U}_{\mathrm{LDPE}} \\
& =5 \mathrm{~kg} \times 670000 \mathrm{~J} / \mathrm{kg}^{\circ} \mathrm{C} \\
& =3350000 \mathrm{~J}
\end{aligned}
$$

$$
\begin{aligned}
& =3350 \mathrm{~kJ} \\
& =\mathrm{m} \cdot \mathrm{C}_{\mathrm{p}} \mathrm{LDPE} \cdot\left(\mathrm{T}_{3}-\mathrm{T}_{2}\right) \\
& =5 \mathrm{~kg} \times 2300 \mathrm{~J} / \mathrm{kg}^{\circ} \mathrm{C} \times(478- \\
& \quad 300) \\
& =2047000 \mathrm{~J} \\
& =2047 \mathrm{~kJ}
\end{aligned}
$$$$
\begin{aligned}
& =\mathrm{Q} 1+\mathrm{Q} 2+\mathrm{Q} 3+\mathrm{Q} 4+\mathrm{Q} 5 \\
& =8187 \mathrm{~kJ}
\end{aligned}
$$

Maka untuk hasil perhitungan nilai kalor optimal dengan $m_{\text {plastik }}=5 \mathrm{~kg}, \eta=30 \%$, laju pembakaran $(\mathrm{Wa})=2[\mathrm{~kg} / \mathrm{jam}]$, dan waktu untuk mencairkan plastik, $\mathrm{t}=1$ [jam], dijabarkan sebagai berikut :

$\mathrm{Np} \quad=\frac{8187 \mathrm{~kJ}}{2 \frac{\mathrm{kg}}{j a m} \times 1 \mathrm{jam} \times 0.3}=13645[\mathrm{~kJ} / \mathrm{kg}]$

Jadi nilai kalor optimal untuk bahan bakar yang dibutuhkan adalah $13645[\mathrm{~kJ} / \mathrm{kg}]$ atau setara dengan 3248.809 [kcal $/ \mathrm{kg}]$.

Untuk laju pembakaran $(\mathrm{Wa})=2[\mathrm{~kg} / \mathrm{jam}]$, maka dapat dihitung untuk kebutuhan energi yang dibutuhkan perhari jika burner bekerja selama 24 jam yaitu : Kebutuhan energi/hari

E

$$
\begin{aligned}
= & \mathrm{Wa} \times \mathrm{t} / \text { hari } \times \eta \times \mathrm{Np} \\
= & 2 \frac{\mathrm{kg}}{j a m} \times 24 \frac{\text { jam }}{\text { hari }} \times 0.3 \times 13645 \\
& {[\mathrm{~kJ} / \mathrm{kg}] } \\
= & 196488[\mathrm{~kJ} / \text { hari }] \text { atau setara dengan } \\
& 46782.857[\mathrm{kcal} / \text { hari }]
\end{aligned}
$$

Maka, total kebutuhan briket RDF dalam satu hari pada satu burner adalah:

$$
\begin{aligned}
\mathrm{M} & =46782.857 \quad \frac{\mathrm{kCal}}{\text { hari }} \times \frac{1}{3248.809} \frac{\mathrm{kg}}{\mathrm{kCal}} \\
& =14.4[\mathrm{~kg} / \mathrm{hari}]
\end{aligned}
$$

Dengan berat satu briket sebesar $20 \mathrm{gr}$, maka dalam satu burner per-harinya akan menghabiskan 720 briket.

\subsection{Hasil Uji Nilai Kalor Briket dengan Bomb Calorimeter}

Hasil uji nilai kalor Briket RDF dengan menggunakan Bomb Calorimeter yang dilakukan di Laboratorium PT. Anugrah Analisis Sempurna adalah sebesar 16609.03 
$[\mathrm{kJ} / \mathrm{kg}] \quad$ setara dengan $3973.45 \quad$ [kcal $/ \mathrm{kg}]$. (ASTM D 240).

Nilai kalor hasil uji briket RDF berada diatas nilai kalor optimal yang dibutuhkan insenerator pirolisis yaitu $3248.809 \quad[\mathrm{kcal} / \mathrm{kg}]$. Dengan demikian, briket tersebut dapat digunakan pada insenerator pirolisis yang telah ditentukan spesifikasinya tersebut dengan perhitungan kebutuhan jumlah briket perharinya sebagai berikut :

Untuk laju pembakaran $(\mathrm{Wa})=2[\mathrm{~kg} / \mathrm{jam}]$, kebutuhan energi yang dibutuhkan perhari jika burner bekerja selama 24 jam yaitu 46782.857 [kcal/hari]. Maka, total kebutuhan briket RDF dalam satu hari pada satu burner dengan nilai kalor per briket sebesar 3973.45 [kcal/kg] adalah:

$$
\begin{aligned}
\mathrm{M} & =46782.857 \frac{\mathrm{kCal}}{\mathrm{hari}} \times \frac{1}{3973.45} \frac{\mathrm{kg}}{\mathrm{kCal}} \\
& =11.77[\mathrm{~kg} / \text { hari }]
\end{aligned}
$$

Dengan berat satu briket sebesar 20 gr, maka dalam satu burner per-harinya akan menghabiskan 589 briket.

- Kadar Air rata-rata briket RDF sebesar $5.56 \%$, persentase kadar air dari pengujian ke-5 sampel tersebut mendekati dengan pengujian yang dilakukan di laboratorium yaitu dengan perolehan persentase kadar air sebesar $4.68 \%$ (dengan metode pengukuran berdasarkan standar 18-NON-2/MU/SMMAA).

- Kadar abu briket RDF yang telah diujikan di laboratorium, yaitu sebesar $11.64 \%$ (dengan standar 18-NON-3/MU/SMMAAS). Kadar abu tersebut tidak memenuhi standar kadar abu briket bio-batubara yang hanya $<10 \%$ (berdasarkan Permen ESDM No. 047 Tahun 2006), [5].

- Hasil pengujian kadar volatile yang dilakukan pada laboratorium PT. Anugrah Analisis Sempurna adalah sebesar 7.81\% (dengan standar 22-0143/IK/SMM-AAS EPA method 24).

- Analisis Fixed Carbon dilakukan untuk mengetahui bagian yang hilang saat proses pembakaran setelah semua kadar volatile hilang pada suhu $750^{\circ} \mathrm{C}$. Berdasarkan hasil uji di Laboratorium PT. Anugrah Analisis
Sempurna, kadar fixed carbon pada briket RDF sampah 4K1P adalah sebesar $75.87 \%$.

\section{KESIMPULAN}

Hasil penelitian ini dapat disimpulkan sebagai berikut:

- Berdasarkan perhitungan teoritis dari enam data nilai kalor referensi, potensi energi sampah 4K1P di TPA Murareja, Kabupaten Tegal sebesar 3677.0945 - 5507.114 $[\mathrm{kcal} / \mathrm{kg}]$. Dengan rata-rata nilai kalor sebesar 4819.220 [kcal $/ \mathrm{kg}]$.

- Berdasarkan hasil uji dengan Bomb Calorimeter yang dilakukan di Laboratorium nilai kalor briket RDF sampah 4K1P adalah sebesar 16609.03 $[\mathrm{kJ} / \mathrm{kg}]$ atau setara dengan 3973.45 $[\mathrm{kcal} / \mathrm{kg}]$. (ASTM D 240).

- Nilai kalor RDF yang dibutuhkan sebagai bahan bakar insenerator pirolisis adalah sebesar $3248.809[\mathrm{kcal} / \mathrm{kg}]$. Dengan laju pembakaran sebesar $(\mathrm{Wa})=2[\mathrm{~kg} / \mathrm{jam}]$, efisiensi thermal $30 \%$, dalam waktu pemanasan selama 1 jam dengan temperatur $478\left[{ }^{\circ} \mathrm{C}\right]$ dengan suhu $\mathrm{T}_{0}=100\left[{ }^{\circ} \mathrm{C}\right]$.

- Persentase komposisi dari tiap-tiap bahan baku penyusun RDF terdiri dari $15.35 \%$ sampah kertas, 1\% sampah kayu, 2\% sampah kain, dan $2.35 \%$ sampah karet/kulit dengan tambahan 8\% sampah plastik. Dengan persentase tersebut, didapatkan perhitungan massa tiap bahan baku adalah 10.70 [gr] kertas, 0.70 [gr] kayu, 1.39 [gr] kain, 1.64 [gr] Karet/Kulit, dan 5.57[gr] plastik. Massa satu briket yang dipilih adalah 20 [gr], dengan diameter briket 1 inch, dan tinggi 7 [cm].

- Berdasarkan hasil uji laboratorium diperoleh persentase kadar air, kadar abu, kadar volatile dan fixed carbon sebagai berikut berturut-turut , 4.68\%, $11.64 \%$, $7.81 \%$, dan $75.87 \%$.

\section{DAFTAR PUSTAKA}

[1] DKP, (2014). Dinas Kebersihan dan Pertamanan Kabupaten Tegal.

[2] Bimantara C. Ardi, (2012). Analisa Potensi Refuse Derived Fuel (RDF) Dari Sampah Unit Pengolahan Sampah (UPS) Di Kota Depok 
(Studi Kasus UPS Grogol, UPS Permata Regency, UPS Cilangkap).

[3] Rania, M.F., Agti, E.V., Sari, I.T.P., Dewi, P.S., (2015). Pemanfaatan Limbah Plastik High Density Polyethylene Untuk Meningkatkan Nilai Kalor Briket Tempurung Kelapa.

[4] Utami, Y., (2008). Desain dan Uji Unjuk Kerja Tungku Briket Biomassa.

[5] Kemen ESDM, (2006). Permen ESDM No.047. Pedoman Pembuatan Dan Pemanfaatan Briket Batubara dan Bahan Bakar Padat Berbasis Batubara. 